\title{
Front Matter: Volume 7603
}

, "Front Matter: Volume 7603," Proc. SPIE 7603, Oxide-based Materials and Devices, 760301 (18 March 2010); doi: 10.1117/12.859315

SPIE. Event: SPIE OPTO, 2010, San Francisco, California, United States 


\section{PROCEEDINGS OF SPIE}

\section{Oxide-based Materials and Devices}

Ferechteh Hosseini Teherani

David C. Look

Cole W. Litton

David J. Rogers

Editors

24-27 January 2010

San Francisco, California, United States

Sponsored and Published by

SPIE

Volume 7603 
The papers included in this volume were part of the technical conference cited on the cover and title page. Papers were selected and subject to review by the editors and conference program committee. Some conference presentations may not be available for publication. The papers published in these proceedings reflect the work and thoughts of the authors and are published herein as submitted. The publisher is not responsible for the validity of the information or for any outcomes resulting from reliance thereon.

Please use the following format to cite material from this book:

Author(s), "Title of Paper," in Oxide-based Materials and Devices, edited by Ferechteh Hosseini Teherani, David C. Look, Cole W. Litton, David J. Rogers, Proceedings of SPIE Vol. 7603 (SPIE, Bellingham, WA, 2010) Article CID Number.

ISSN 0277-786X

ISBN 9780819479990

Published by

SPIE

P.O. Box 10, Bellingham, Washington $98227-0010$ USA

Telephone +1 3606763290 (Pacific Time) · Fax +1 3606471445

SPIE.org

Copyright @ 2010, Society of Photo-Optical Instrumentation Engineers

Copying of material in this book for internal or personal use, or for the internal or personal use of specific clients, beyond the fair use provisions granted by the U.S. Copyright Law is authorized by SPIE subject to payment of copying fees. The Transactional Reporting Service base fee for this volume is $\$ 18.00$ per article (or portion thereof), which should be paid directly to the Copyright Clearance Center (CCC), 222 Rosewood Drive, Danvers, MA 01923. Payment may also be made electronically through CCC Online at copyright.com. Other copying for republication, resale, advertising or promotion, or any form of systematic or multiple reproduction of any material in this book is prohibited except with permission in writing from the publisher. The CCC fee code is 0277-786X/10/\$18.00.

Printed in the United States of America.

Publication of record for individual papers is online in the SPIE Digital Library.

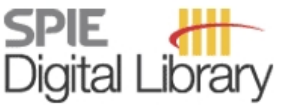

SPIEDigitalLibrary.org

Paper Numbering: Proceedings of SPIE follow an e-First publication model, with papers published first online and then in print and on CD-ROM. Papers are published as they are submitted and meet publication criteria. A unique, consistent, permanent citation identifier (CID) number is assigned to each article at the time of the first publication. Utilization of CIDs allows articles to be fully citable as soon they are published online, and connects the same identifier to all online, print, and electronic versions of the publication. SPIE uses a six-digit CID article numbering system in which:

- The first four digits correspond to the SPIE volume number.

- The last two digits indicate publication order within the volume using a Base 36 numbering system employing both numerals and letters. These two-number sets start with 00, 01, 02, 03, 04 , 05, 06, 07, 08, 09, OA, OB ... 0Z, followed by 10-1Z, 20-2Z, etc.

The CID number appears on each page of the manuscript. The complete citation is used on the first page, and an abbreviated version on subsequent pages. Numbers in the index correspond to the last two digits of the six-digit CID number. 


\section{Contents}

ix Conference Committee

xi In Memoriam: Cole W. Litton (Sept. 29, 1930 - Jan. 26, 2010)

SESSION 1 ZNO-BASED MATERIALS: ELECTRONIC STRUCTURE, TRANSPORT, EMISSION, ABSORPTION, AND POLARITY I

760303 Theory of high field carrier transport and impact ionization in ZnO (Invited Paper) [7603-02] F. Bertazzi, M. Penna, Boston Univ. (United States) and Politecnico di Torino (Italy); M. Goano, Politecnico di Torino (Italy); E. Bellotti, Boston Univ. (United States)

760304 Ultrafast carrier relaxation and diffusion dynamics in ZnO (Invited Paper) [7603-03]

C. J. Cook, Univ. of Florida (United States); S. Khan, Univ. of Illinois (United States);

G. D. Sanders, Univ. of Florida (United States); X. Wang, The Univ. of Texas at Austin (United States); D. H. Reitze, Univ. of Florida (United States); Y. D. Jho, Gwangju Institute of Science and Technology (Korea, Republic of); Y.-W. Heo, J.-M. Erie, D. P. Norton, C. J. Stanton, Univ. of Florida (United States)

SESSION 2 ZNO-BASED MATERIALS: ELECTRONIC STRUCTURE, TRANSPORT, EMISSION, ABSORPTION, AND POLARITY II

760306 Properties of zinc oxynitride films deposited by reactive magnetron sputtering at room temperature (Invited Paper) [7603-05]

J. L. Pau, M. J. Hernández, M. Cervera, E. Ruiz, J. Piqueras, Univ. Autónoma de Madrid (Spain)

760307 Growth and properties of nonpolar and polar MgZnO/ZnO quantum structures (Invited Paper) [7603-06]

H. Matsui, H. Tabata, The Univ. of Tokyo (Japan)

\section{SESSION 3 USE OF ZNO AND TCO IN PHOTOVOLTAICS}

7603 OB ZnO transparent conductive oxide for thin film silicon solar cells (Invited Paper) [7603-09] T. Söderström, D. Dominé, A. Feltrin, M. Despeisse, F. Meillaud, G. Bugnon, M. Boccard, P. Cuony, F.-J. Haug, S. Fä̈, S. Nicolay, C. Ballif, École Polytechnique Fédérale de Lausanne (Switzerland)

7603 OC Transparent conductive oxides for organic photovoltaics (Invited Paper) [7603-10] G. B. Murdoch, D. Gao, M. Greiner, L. Mordoukhovski, Univ. of Toronto (Canada); J. Zhang, Z. H. LU, Yunnan Univ. (China) and Univ. of Toronto (Canada)

7603 OD Growth and characterization of ZnO-based buffer layers for CIGS solar cells (Invited Paper) [7603-12] T. Törndahl, A. Hultqvist, C. Platzer-Björkman, M. Edoff, Uppsala Univ. (Sweden) 
7603 OF Band gap engineering of ZnO for high efficiency CIGS based solar cells (Invited Paper) [7603-14]

C. Platzer-Björkman, A. Hultqvist, J. Pettersson, T. Törndahl, Uppsala Univ. (Sweden)

$76030 \mathrm{G}$ Self textured transparent conductive oxide film for efficiency improvement in solar cell (Invited Paper) [7603-15]

D. Kim, Yonsei Univ. (Korea, Republic of); J. Yi, Sungkyunkwan Univ. (Korea, Republic of);

H. Kim, Yonsei Univ. (Korea, Republic of)

\section{SESSION 4 DOPING STUDIES OF ZNO}

7603 0J Hydrogen in ZnO (Invited Paper) [7603-18]

E. V. Lavrov, Technische Univ. Dresden (Germany)

7603 OK Lattice location of the group V elements Sb, As, and P in ZnO (Invited Paper) [7603-19]

U. Wahl, Instituto Tecnológico e Nuclear (Portugal) and Univ. de Lisboa (Portugal);

J. G. Correia, Instituto Tecnológico e Nuclear (Portugal), Univ. de Lisboa (Portugal) and CERN-PH (Switzerland); T. Mendonça, Univ. do Porto (Portugal); S. Decoster, Katholieke Univ. Leuven (Belgium)

\section{SESSION $5 \quad$ PROGRESS IN SPIN-BASED MATERIALS AND DEVICES}

$760300 \quad$ Functionalization of multiferroic oxide structures for spintronic devices (Invited Paper) [7603-23]

C.-L. Jia, J. Berakdar, Martin-Luther Univ. Halle-Wittenberg (Germany)

\section{SESSION 6 GROWTH AND PROPERTIES OF MULTIFUNCTIONAL OXIDES I}

$7603 \mathrm{OR}$ Atomic layer epitaxy of $\mathrm{ZnO}$ and $\mathrm{TiO}_{2}$ thin films on c-plane sapphire substrate for novel oxide soft $x$-ray mirrors [7603-60]

M. Murata, Y. Tanaka, H. Kumagai, Osaka City Univ. (Japan); T. Shinagawa, Osaka

Municipal Technical Research Institute (Japan); A. Kobayashi, Osaka City Univ. (Japan)

\section{SESSION 7 GROWTH AND PROPERTIES OF MULTIFUNCTIONAL OXIDES II}

7603 OU Interface control in $\mathrm{BaTiO}_{3}$ based supercapacitors (Invited Paper) [7603-28]

M. Maglione, C. Elissalde, U.-C. Chung, ICMCB CNRS, Univ. Bordeaux 1 (France)

7603 OV Molecular dynamics simulation of metal oxide growth on $\mathrm{SrTiO}_{3}$ (Invited Paper) [7603-29] J. L. Wohlwend, Univ. of Florida (United States); C. N. Boswell-Koller, Univ. of California, Berkeley (United States); S. R. Phillpot, S. B. Sinnott, Univ. of Florida (United States)

7603 OW Enhanced transport properties in $\mathrm{La}_{x} \mathrm{MnO}_{3-\delta}$ thin films grown on $\mathrm{SrTiO}_{3}$ substrates (Invited Paper) [7603-30]

P. Orgiani, A. Galdi, CNR-INFM Coherentia (Italy) and Univ. of Salerno (Italy); C. Aruta, CNR-INFM Coherentia (Italy) and Univ. of Napoli (Italy); R. Ciancio, CNR-INFM National Lab. TASC (Italy); U. Lüders, R. V. K. Mangalam, W. Prellier, Lab. CRISMAT, ENSICAEN, CNRS (France); L. Maritato, CNR-INFM Coherentia (Italy) and Univ. of Salerno (Italy) 
7603 0X Plasmonic effects on the laser-induced metal-insulator transition of vanadium dioxide (Invited Paper) [7603-31]

D. W. Ferrara, E. R. MacQuarrie, J. Nag, R. F. Haglund, Jr., Vanderbilt Univ. (United States)

\section{SESSION 8 OXIDE-BASED TRANSISTORS AND TRANSPARENT ELECTRONICS I}

760310 High performance transparent thin film transistor with atomic layer deposition ZnO based active channel layer (Invited Paper) [7603-34]

H. Kim, S. J. Lim, J.-M. Kim, D. Y. Kim, Yonsei Univ. (Korea, Republic of)

760311 Complementary use of organic and oxide semiconductors (Invited Paper) [7603-35]

J. H. Na, M. Kitamura, Y. Arakawa, The Univ. of Tokyo (Japan)

760313 Review on optical and electrical properties of oxide semiconductors (Invited Paper)

[7603-11]

D. L. Kim, H. J. Kim, Yonsei Univ. (Korea, Republic of)

\section{SESSION 9 OXIDE-BASED TRANSISTORS AND TRANSPARENT ELECTRONICS II}

$760314 \quad$ Floating gate memory paper transistor [7603-37]

R. Martins, L. Pereira, P. Barquinha, N. Correia, G. Gonçalves, I. Ferreira, C. Dias, E. Fortunato, CENIMAT, Univ. Nova de Lisboa (Portugal) and CEMOP-UNINOVA (Portugal)

760315 Oxide thin film transistors on novel flexible substrates (Invited Paper) [7603-38]

S. J. Pearton, W. Lim, E. Douglas, F. Ren, Univ. of Florida (United States); Y. W. Heo, Kyungpook National Univ. (Korea, Republic of); D. P. Norton, Univ. of Florida (United States)

760316 Photosensor application of amorphous InZnO-based thin film transistor (Invited Paper) [7603-39]

P.-T. Liu, Y.-T. Chou, L.-F. Teng, National Chiao Tung Univ. (Taiwan)

760318 Thin film transistors with wurtzite $\mathrm{ZnO}$ channels grown on $\mathrm{Si}_{3} \mathrm{~N}_{4} / \mathrm{SiO}_{2} / \mathrm{Si}$ (111) substrates by pulsed laser deposition [7603-41]

D. J. Rogers, Nanovation SARL (France); V. E. Sandana, Nanovation SARL (France) and Northwestern Univ. (United States); F. H. Teherani, Nanovation SARL (France); M. Razeghi, Northwestern Univ. (United States)

\section{SESSION 10 USE OF ZNO FOR UV APPLICATIONS}

7603 IA Optical properties of metal-semiconductor-metal ZnO UV photodetectors [7603-43]

L. Li, Univ. of Missouri, Columbia (United States); Y. Ryu, MOXtronics, Inc. (United States);

H. W. White, Univ. of Missouri, Columbia (United States) and MOXtronics, Inc. (United States);

P. Yu, Univ. of Missouri, Columbia (United States)

7603 IB Cubic $\mathrm{Zn}_{\mathbf{x}} \mathrm{Mg}_{1-\mathrm{x}} \mathrm{O}$ and $\mathrm{Ni}_{\mathrm{x}} \mathrm{Mg}_{1-\mathrm{x}} \mathrm{O}$ thin films grown by molecular beam epitaxy for deep-UV optoelectronic applications (Invited Paper) [7603-44]

J. W. Mares, C. R. Boutwell, A. Scheurer, M. Falanga, W. V. Schoenfeld, CREOL, The College of Optics and Photonics, Univ. of Central Florida (United States) 
7603 1D Epitaxial MOVPE growth of highly c-axis oriented InGaN/GaN films on ZnO-buffered Si (111) substrates (Invited Paper) [7603-46]

A. Ougazzaden, Georgia Institute of Technology Lorraine (France); D. J. Rogers,

F. H. Teherani, Nanovation SARL (France); G. Orsal, T. Moudakir, S. Gautier, LMOPS, CNRS, Univ. de Metz et SUPELEC (France); V. E. Sandana, Nanovation SARL (France); F. Jomard, Univ. de Versailles-Saint-Quentin (France); M. Abid, Georgia Institute of Technology Lorraine (France); M. Molinari, M. Troyon, Univ. of Reims Champagne-Ardennes (France); P. L. Voss, Georgia Institute of Technology Lorraine (France); D. McGrouther, J. N. Chapman, Univ. of Glasgow (United Kingdom)

\section{SESSION 11 NANOSTRUCTURED OXIDES AND THEIR APPLICATIONS I}

$76031 \mathrm{H} \quad$ Nanopatterned optical and magnetic $\mathrm{La}_{0.7} \mathrm{Sr}_{0.3} \mathrm{MnO}_{3}$ arrays: synthesis, fabrication, and properties (Invited Paper) [7603-50]

M.-C. Wu, National Taiwan Univ. (Taiwan); C.-M. Chuang, Institute of Nuclear Energy Research (Taiwan); Y.-C. Huang, Y.-J. Wu, National Taiwan Univ. (Taiwan); K.-C. Cheng, National Taipei Univ. of Technology (Taiwan); C.-F. Lin, Y.-F. Chen, W.-F. Su, National Taiwan Univ. (Taiwan)

$760311 \quad$ Multi-layered water quality sensor based on $\mathbf{R u O}_{2}$ nanostructures (Invited Paper) [7603-51] S. Zhuiykov, Commonwealth Scientific and Industrial Research Organisation (Australia)

\section{SESSION 12 NANOSTRUCTURED OXIDES AND THEIR APPLICATIONS II}

$76031 \mathrm{~J} \quad$ Nanolithography for oxide nanoarrays and their application in medical devices (Invited Paper) [7603-52]

R. Luttge, Univ. of Twente (Netherlands)

$76031 \mathrm{~L}$ Effect of surface modification on the optical properties of nanocrystalline zinc oxide materials [7603-54]

J. W. Soares, D. M. Steeves, U.S. Army Natick Soldier Research, Development \& Engineering Ctr. (United States); J. Singh, J. Im, J. E. Whitten, Univ. of Massachusetts, Lowell (United States)

\section{POSTER SESSION}

760310 Characterization of ZnO UV photoconductors on the 6H-SiC substrate [7603-58]

L. Li, Univ. of Missouri, Columbia (United States); Y. Ryu, MOXtronics, Inc. (United States);

H. W. White, Univ. of Missouri, Columbia (United States) and MOXtronics, Inc. (United States);

P. Yu, Univ. of Missouri, Columbia (United States)

7603 IP Structural and electrical properties of rectifying p-ZnO/n+-InP heterojunction [7603-59]

A. Mandal, S. Chakrabarti, Indian Institute of Technology (India)

7603 IR Post-annealing of p-type ZnO:Sb thin film grown by pulsed laser deposition [7603-62]

Y. Yata, T. Sakano, M. Obara, Keio Univ. (Japan) 
$76031 \mathrm{U}$ Structural and optical properties of $\mathrm{TiO}_{2}$ thin films annealed in $\mathrm{O}_{2}$ and $\mathrm{N}_{2}$ gases flow [7603-65] S. H. Kim, T. U. Kim, D. G. Kim, H. C. Ki, Korea Photonics Technology Institute (Korea, Republic of); G.-Y. Oh, Chung-Ang Univ. (Korea, Republic of); H. J. Kim, H. J. Ko, M.-S. Han, S. Hann, H. J. Kim, Korea Photonics Technology Institute (Korea, Republic of)

$76031 \mathrm{~V}$ Physical properties of $\mathrm{MgZnO}$ film grown by $\mathrm{RF}$ magnetron sputtering using $\mathrm{ZnO} / \mathrm{MgO}$ (80/20 wt\%) target [7603-66]

K.-P. Hsueh, Vanung Univ. (Taiwan); C.-J. Tun, National Synchrotron Radiation Research Ctr. (Taiwan); H.-C. Chiu, Chang Gung Univ. (Taiwan)

Author Index 
Downloaded From: https://www.spiedigitallibrary.org/conference-proceedings-of-spie on 26 Apr 2023

Terms of Use: https://www.spiedigitallibrary.org/terms-of-use 


\title{
Conference Committee
}

\author{
Symposium Chair
}

E. Fred Schubert, Rensselaer Polytechnic Institute (United States)

Symposium Cochairs

Liang-Chy Chien, Kent State University (United States)

James G. Grote, Air Force Research Laboratory (United States)

Program Track Chair

James G. Grote, Air Force Research Laboratory (United States)

Conference Chairs

Ferechteh Hosseini Teherani, Nanovation SARL (France)

David C. Look, Wright State University (United States)

Cole W. Litton, Air Force Research Laboratory - retired (United States)

David J. Rogers, Nanovation SARL (France)

Program Committee

Rodrigo Ferrão de Paiva Martins, Uninova/CEMOP (Portugal)

Elvira M. C. Fortunato, Universidade Nova de Lisboa (Portugal)

Hiroshi Fujioka, The University of Tokyo (Japan)

Michael D. Gerhold, U.S. Army Research Office (United States)

Hanns-Ulrich Habermeier, Max-Planck-Institut für Festkörperforschung (Germany)

Masashi Kawasaki, Tohoku University (Japan)

Tatsuo Okada, Kyushu University (Japan)

Stuart S. P. Parkin, IBM Almaden Research Center (United States)

Manijeh Razeghi, Northwestern University (United States)

Donald J. Silversmith, Air Force Office of Scientific Research (United

States)

Zhong Lin Wang, Georgia Institute of Technology (United States)

Session Chairs

1 ZnO-based Materials: Electronic Structure, Transport, Emission, Absorption, and Polarity I

David C. Look, Wright State University (United States) 
2 ZnO-based Materials: Electronic Structure, Transport, Emission,

Absorption, and Polarity II

David C. Look, Wright State University (United States)

3 Use of $\mathrm{ZnO}$ and TCO in Photovoltaics

David J. Rogers, Nanovation SARL (France)

Jose Luis Pau Vizcaino, Universidad Autónoma de Madrid (Spain)

4 Doping Studies of $\mathrm{ZnO}$

Bruno Masenelli, Université Claude Bernard Lyon 1 (France)

$5 \quad$ Progress in Spin-based Materials and Devices

Chenglong Jia, Martin-Luther-Universität Halle-Wittenberg (Germany)

6 Growth and Properties of Multifunctional Oxides I

Hanns-Ulrich Habermeier, Max-Planck-Institut für Festkörperforschung (Germany)

Pasquale Orgiani, Università degli studi di Salerno (Italy)

7 Growth and Properties of Multifunctional Oxides II

Hanns-Ulrich Habermeier, Max-Planck-Institut für Festkörperforschung (Germany)

Pasquale Orgiani, Università degli studi di Salerno (Italy)

8 Oxide-based Transistors and Transparent Electronics I

Elvira M. C. Fortunato, Universidade Nova de Lisboa (Portugal)

Stephen J. Pearton, University of Florida (United States)

9 Oxide-based Transistors and Transparent Electronics II

Erica Douglas, University of Florida (United States)

Stephen J. Pearton, University of Florida (United States)

10 Use of ZnO for UV Applications

David J. Rogers, Nanovation SARL (France)

David C. Look, Wright State University (United States)

11 Nanostructured Oxides and their Applications I

Yicheng Lu, Rutgers, The State University of New Jersey (United States)

Diane M. Steeves, U.S. Army Soldier Systems Center (United States)

12 Nanostructured Oxides and their Applications II

Regina Luttge, Universiteit Twente (Netherlands)

Tatsuo Okada, Kyushu University (Japan) 


\section{In Memoriam}

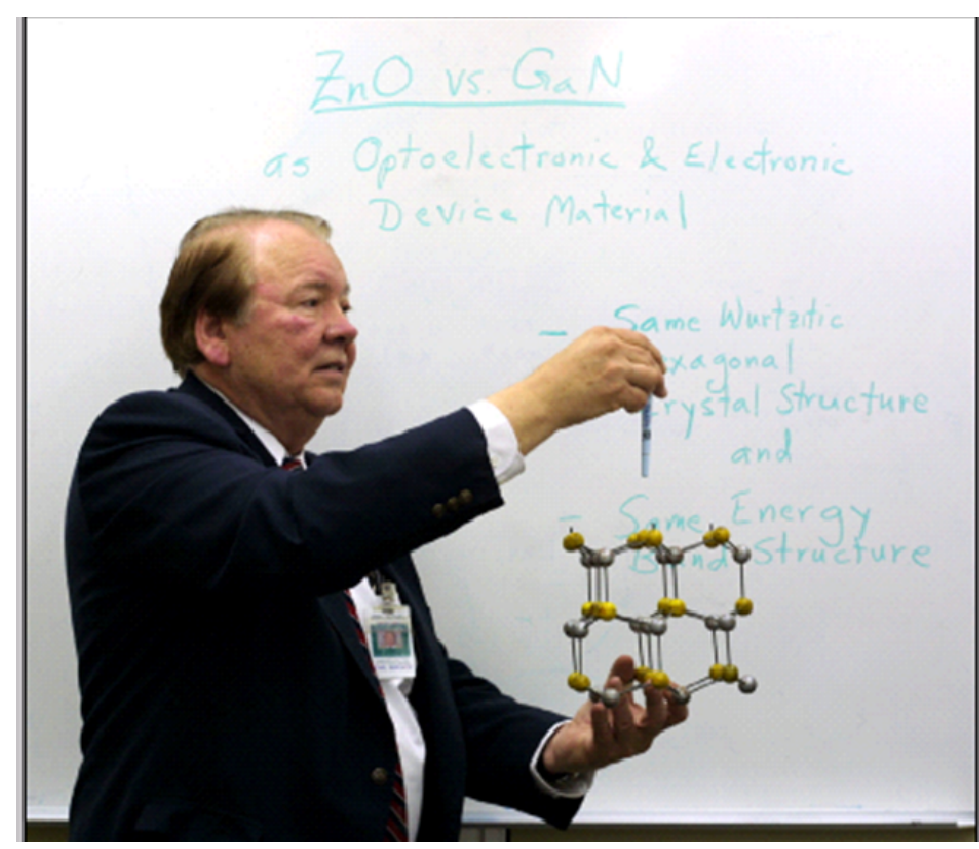

\section{Cole W. Litton}

Sept. 29, 1930 - Jan. 26, 2010

These proceedings are dedicated to the memory of Dr. Cole Litton, who passed away while attending the Photonics West 2010 symposium. The oxide semiconductor community will forever be indebted to Cole for his enthusiasm, kindness and tireless efforts to promote research into zinc oxide for optoelectronics applications. 
Downloaded From: https://www.spiedigitallibrary.org/conference-proceedings-of-spie on 26 Apr 2023

Terms of Use: https://www.spiedigitallibrary.org/terms-of-use 